\title{
Kericserispira nomen novum, a new substitute name instead of Foveolaria Szabó, 2017 (non Foveolaria Busk, 1884)
}

\author{
János SzABó \\ Department of Palaeontology and Geology, Hungarian Natural History Museum, \\ H-1083 Budapest,Ludovika tér 2, Hungary.E-mail:szabo.janos@nhmus.hu
}

To distinguish the gastropod morphology, which had been first represented in the literature by the varieties of "Pleurotomaria foveolata" J. A. EudesDeslongchamps, 1849, Szabó (2017) outlined a new genus under the name Foveolaria. However, this name had already been preoccupied by BUSK (1884) for a bryozoan genus; its new use meant making a junior (invalid) homonym. To replace that, Kericserispira nomen novum is instituted here in accordance with ICZN Article 60.3 beside the same diagnosis, type species, further included species and higher systematic position as they have been assigned to the invalid name (Szaвó 2017, p. 13).

Etymology - Kericser is a hillside SW of the village Lókút (Bakony Mts, Hungary) with an excavation in Lower Jurassic Hierlatz Limestone that has yielded specimens of the type species; spira $($ Latin $)=$ spiral.

Acknowledgement - I am thankful to Philippe Bouchet (Muséum National d'Histoire Naturelle, Paris) who has called my attention to the above fault.

\section{REFERENCES}

Busk G. 1884: Report on the Polyzoa collected by H. M. S. Challenger during the years 1873-76. In: ThOMSON C. W. \& MURRAY J. (Eds): Report on the scientific results of the voyage of H. $M$. $S$. Challenger: during the years 1873-76: under the command of Captain George S. Nares, R. N. F. R. S. and the late Captain Frank Tourle Thomson, R. N., Zoology X., xxiii + 216 pp, Pls 1-36. ICZN, International Commission on Zoological Nomenclature 1999: International Code of Zoological Nomenclature. - Fourth Edition, XXIX + 306 pp., London, International Trust for Zoological Nomenclature. - http://www.iczn.org/iczn/index.jsp

SzABó J. 2017: Gastropods of the Lower Jurassic Hierlatz Limestone Formation, part 2. Some new archaic type slit-bearing components from the fauna of the Hierlatz Alpe (Hallstatt, Austria) and the Bakony Mts (Hungary). - Fragmenta Palaeontologica Hungarica 33: 3-30. https://doi.org/10.17111/FragmPalHung.2016.33.3 